\title{
Cuatro siglos de historia literaria
}

Sea en 1535 o en 1539 cuando se imprimió el primer libro, México tuvo en este hemisferio la primera imprenta. Las investigaciones, que a veces culminan en polémica en torno al año memorable, continúan - para bien de la historia de la cultura hispánica- iluminando recintos que estaban sumergidos en la oscuridad, y enriqueciendo la importancia de un hecho que, por sí solo, viene a ser el de más ilustre rango después de la hazaña colombina.

Es de tal magnitud el acontecimiento cuyo cuarto centenario festeja la hispanidad, y tan esencial en los orígenes de la Amé-. rica Nueva, que así como la cultura de la América Antigua parece haber comenzado con la domesticación del maíz, así la hispanoatlántica se inicia cuando los tipos movibles de Gutenberg en manos de Juan Pablos ponen en movimiento una muchedumbre de formas y de ideas que son, a su vez, presencia de las letras que buscaban nueva expresión.

Juan de Zumárraga, Antonio de Mendoza, Alonso de la Veracruz y Juan de Cárdenas animan el aire de una cultura renaciente, en la que al injertarse los valores de lo americano darían otra dimensión al idioma imperial que aún no tiene ocaso.

La imprenta se estableció cuando no se había tomado posesión definitiva de la tierra, cuando se esbozaban los múltiples 
problemas de la nueva sociedad, y cuando se necesitaba más de evangelizadores que de hombres de letras, si bien éstos llegaron con los mismos conquistadores - dos de ellos Hernán Cortés y Bernal Díaz del Castillo - ya que no sólo sabían vestir bien su pensamiento, enriquecer su emoción en la palabra, trasplantar a la acción los sueños de los libros de caballería y remozar el romance castellano en una atmósfera épica.

\author{
En Tacuba está Cortés \\ con su - escuadrón esforzado..., \\ la una mano en la mejilla \\ y la otra en el costado.
}

Pero la imprenta no había de prestar sus primeros servicios al ingenio español, sino a la política evangelizadora. Las letras adquirían la función de inculcar en la mente del franciscano las nociones preliminares de las lenguas y los dialectos aborígenes para facilitar tamaña empresa. $\mathrm{Y}$ así como las primeras escuelas - a la vanguardia la de Tlaltelolco- no fueron para los hijos de los españoles, sino para beneficio de los hijos de los caciques y para orientar a los conquistadores con la cruz, así el libro fué el más decidido colaborador en el programa de sojuzgar al indio.

Las primeras publicaciones fueron didácticas: confesionarios, vocabularios, sermonarios, en mexicano, en tarasco, en zapoteco. Y los próceres escritores se llamaron Zumárraga, Alonso de Molina, Maturino de Gilberti, Juan de Gaona. Puede aventurarse la afirmación de que el primer libro que tuvo ya un sabor primicial en la historia del castellano, a pesar de que propendía a divtlgar conocimientos populares y riquezas biológicas, fué el del doctor Juan de Cárdenas: Primera parte de los problemas, y secretos maravillosos de las Indias, editado por Pedro Ocharte en I591. Con él hace acto de presencia la que bien pronto fué rica literatura de cronistas de Indias, dibujando el extraordinario mundo que les fascinaba, y dando validez en nues- 
tro idioma a una multitud de palabras novísimas, que pronto serían la base del castellano de América.

Las cartas y relatos oficiales o de carácter confidencial que los súbditos enviaban al Rey, tienen lugar primerísimo en la biografía de nuestro castellano. Las tesis universitarias, por estar escritas en latín, lo mismo que las disquisiciones teológicas o las conexas con el Derecho Canónico, nada tienen que ver con esa literatura incipiente, y los mismos Diálogos de Cervantes de Salazar se incorporaron a la historia de lo hispanomexicano hasta que la sabiduría de García Icazbalceta los puso en nuestra prosa.

Es en el siglo XVII cuando los poetas y los cronistas y los oradores religiosos dieron a conocer los frutos de su ingenio o de su erudición en páginas que son gala y prez de una tipografía que puede llamarse francamente mexicana.

No deja de ser, pues, en extremo apasionante el estudio de la historia de la imprenta en América. Ella refleja las preocupaciones, los problemas, las inquietudes de un mundo que se renovaba a pesar del aislamiento a que lo condenaba la metrópoli. De vez en cuando asomaba la rebeldía en el textó gracioso de un pasquín o en el romance callejero, anónimo, que las manos ágiles de la Inquisición atrapaban. Y hasta 1722 , cuando apareció la “Gazeta de México", el primer periódico, la noticia europea constituyó un artículo de primera necesidad para el reducido público que leía aquel impreso tan desprovisto de informaciones mexicanas, pero que bien pronto, con su ausencia, demostró que la historia de la imprenta se halla íntimamente vinculada a las vicisitudes de las ideas políticas.

Es de notarse el hecho de que, aun después de emancipada la América Española, el periodismo siguió siendo la mejor tribuna de la expresión literaria, aquella en que los afortunados ingenios harían sus primeros ensayos, pasando por las disciplinas de la publicidad diaria. Vemos así que desde Fernández de Lizardi hasta Gutiérrez Nájera, desde Altamirano y Martí has- 
ta Sarmiento, los mejores escritores hispanoamericanos han pasado por ese terrible crisol.

En el cuarto centenario del establecimiento formal de la imprenta en América, el homenaje de los espíritus se inclina ante el recuerdo de Zumárraga, Cromberger y Juan Pablos, los tres varones que dieron al libro una nueva categoría y le confiaron un mensaje. $Y$ no podemos olvidar a quienes han labrado un digno monumento a la producción impresa: Beristáin de Souza, García Icazbalceta, José Toribio Medina, René Moreno y Carlos M. Trelles. La bibliografía y las letras americanas acuden por diversos caminos a participar en el venturoso jubileo.

Rafael Heliodoro Valle.

Véase la bibliografía en la sección correspondiente. 